\title{
Correspondence
}

\section{Comparison of IV salbutamol with IV aminophylline in severe acute asthma}

Sir,

In a double-blind comparative study of children with acute asthma, Hambleton and Stone (Archives, 1979, 54, 391) showed that IV salbutamol and aminophylline were equally effective when given during the first 24 hours.

The optimal use of theophylline requires a dosage regimen that maintains the serum concentration within the therapeutic range of 10-20 mg/l (Jenne et al., 1972; Weinberger and Bronsky, 1974). Hambleton and Stone used a loading dose of $4 \mathrm{mg} / \mathrm{kg}$ followed by $0.6 \mathrm{mg} / \mathrm{kg}$ per hour. In a recent study (Selvig et al., 1979), despite a bigger loading dose of $5 \mathrm{mg} / \mathrm{kg}$ in slightly older children (aged 8-15 years), therapeutic values were reached in only $62 \%$ of them and maximum serum concentration in each case was in the lower half of the range. A more suitable loading dose would have been $7.5 \mathrm{mg} / \mathrm{kg}$, which is tolerated by most children, with average serum concentrations in the middle of the range (Weinberger, 1978). Furthermore, the infusion rate of $0.6 \mathrm{mg} / \mathrm{kg}$ per hour is much lower than the $0.85 \mathrm{mg} / \mathrm{kg}$ per hour recommended to maintain therapeutic serum concentrations in children less than 9 years (Hendeles and Weinberger, 1979).

The similar clinical effect shown by Hambleton and Stone when aminophylline dosage was subtherapeutic suggests to us that a different conclusion might have been reached had a therapeutic dose of aminophylline been used.

\section{References}

Hendeles, L., and Weinberger, M. (1979). Letter: Guidelines for avoiding theophylline overdose. New England Journal of Medicine, 300, 1217.

Jenne, J. W., Wyze, E., Rood, F. S., and MacDonald, F. M. (1972). Pharmacokinetics of theophylline. Application to adjustment of the clinical dose of aminophylline. Clinical Pharmacology and Therapeutics, 13, 349-360.

Selvig, K., Holmen, T. L., Aas, K., Rugstad, H. E., and Bjerve, K. S. (1979). Serum concentrations of theophylline in children following the administration of doses generally recommended: new dosage regimen required. Acta paediatrica Scandinavica, 68, 435-439.

Weinberger, M. (1978). Theophylline for treatment of asthma. Journal of Pediatrics, 92, 1-7.

Weinberger, M. M., and Bronsky, E. A. (1974). Evaluation of oral bronchodilator therapy in asthmatic children. Journal of Pediatrics, 84, 421-427.

\section{BLumenthal AND W. P. TORMEY Department of Paediatrics, Leeds General Infirmary, Great George Street, Leeds 1}

Drs Hambleton and Stone comment:

We note the criticism about the dose of aminophylline and make the following comments. The assertion that therapeutic efficacy will be achieved when serum theophylline is $10-20 \mathrm{mg} / 1$ is based on the use of oral theophylline compounds in the prophylaxis of perennial asthma (Jenne et al., 1972; Weinberger and Bronsky, 1974). Weinberger et al. (1976) gave data on acute asthma in children and evaluated the dosages necessary to maintain the above level. However, their paper did not indicate how effective their regimen was in terms of producing relief from asthma. Turner-Warwick (1957) studied acute wheezing in adults, and judged the appropriate serum levels simply from reports from patients on the subjective relief of symptoms after oral theophylline compounds. Selvig et al. (1979) studied serum theophylline levels after a single IV dose of aminophylline, and recommended a loading dose of $6 \mathrm{mg} / \mathrm{kg}$ but gave no information about maintenance treatment. Weinberger (1978) recommended a loading dose of aminophylline $5 \mathrm{mg} / \mathrm{kg}$, and although he suggested $7.5 \mathrm{mg} / \mathrm{kg}$ in some children he pointed out that this dose would be toxic in others. Weinberger (1978) and Hendeles and Weinberger (1979) recommended $0.8 \mathrm{mg} / \mathrm{kg}$ per hour and $0.85 \mathrm{mg} / \mathrm{kg}$ per hour respectively as maintenance therapy, but gave no indication that these doses were necessary for relief of symptoms in acute asthma. They recommended that serial theophylline estimations should be carried out for patients individually, which is the ideal modus operandi.

In a double-blind trial such as ours, serum theophylline estimations during treatment are precluded. Pierson et al. (1974) used virtually the same dosage regimen as we did, and produced objective evidence that this was effective in acute asthma. In routine practice we have also found this regimen effective and so adopted it for the trial, being confident that there would be no side effects. It also facilitated the pharmaceutical preparation of our ampoules for the double-blind design, having regard to the dosage of salbutamol. We feel our results support those of Pierson et al. (1974) by providing objective evidence that this regimen is effective in acute asthma. The assertion that our dose of aminophylline is subtherapeutic is not justifiable. It is possible that a higher dose might have been more effective, but another double-blind trial would be necessary to establish this point.

\section{References}

Pierson, W. E., Bierman, C. W., and Kelley, V. C. (1974). A double-blind trial of corticosteroid therapy in status asthmaticus. Pediatrics, 54, 284-288.

Turner-Warwick, M. (1957). Study of theophylline plasma levels after oral administration of new theophylline compounds. British Medical Journal, 2, 67-69.

Weinberger, M. W., Matthay, R. A., Ginchansky, E. J., Chidsey, C. A., and Petty, T. L. (1976). Intravenous aminophylline dosage. Use of serum theophylline measurement for guidance. Journal of the American Medical Association, 235, 2110-2113.

G. Hambleton and M. J. Stone Department of Paediatrics, Park Hospital, Davyhulme, Manchester M31 3SL 